\title{
Thickness of the midventricular left ventricular wall is predictive of survival in different forms of cardiac amyloidosis
}

\author{
Fabian aus dem Siepen ${ }^{*}$, Rebekka Kammerer, Katrin A Scherer, Ralf Bauer, Stefan E Hardt, Evangelos Giannitsis, \\ Sebastian Buss, Arnt V Kristen
}

From 16th Annual SCMR Scientific Sessions

San Francisco, CA, USA. 31 January - 3 February 2013

\section{Background}

Systemic amyloidosis is a disorder characterized by extracellular deposition of different insoluble protein fibrils in various organs leading to organ dysfunction. Cardiac involvement is associated with limited survival. We aimed to use cardiac magnetic resonance imaging (CMR) to identify structural and functional alterations related to the different forms of amyloidosis, e. g. hereditary and wild-type transthyretin (TTR) amyloidosis as well as light-chain (AL) amyloidosis.

\section{Methods}

In total, 130 patients (82 male, 38 female; mean age 60.7 \pm 1.1 years) with different forms of amyloidosis (AL $n=72$, TTR $n=58$ ) were evaluated by two blinded experienced observers employing a Vector-ECG gated 1.5T wholebody CMR (Achieva Intera ${ }^{\circledR}$ Philips Medical Systems, Best, The Netherlands). The study included SSFP and gadolinium contrast delayed enhancement (CE-CMR) 2,3-,4-chamber and short-axis planes. EDV, ESV, EF and myocardial mass were analyzed on a standard workstation (Philips Viewform). Regional wall thickness was analyzed in modified 16 segment AHA-model of the left ventricle as well as the interatrial wall and compared between the different forms of amyloidosis. Univariate and multivariate analysis were performed to define predictors of survival.

\section{Results}

Patients with TTR amyloidosis were significantly older as compared to patients with AL. They had higher left ventricular mass $(171.9 \pm 8.1 \mathrm{~g}$ vs. $146.1 \pm 6.9 \mathrm{~g}, \mathrm{p}<0.01)$ and thickness of interatrial septum $(7.3 \pm 0.3 \mathrm{~mm}$ vs. $5.7 \pm 0.2 \mathrm{~mm}$; $\mathrm{p}<0.001)$ with highest LV mass and thickness of interatrial septum in patients with wild-type amyloidosis $(\mathrm{n}=26)$. Distribution of regional wall thickness is shown in figure 1. In AL patients univariate analysis revealed median of maximal wall thickness of the basal $(14 \mathrm{~mm})$, midventricular $(10 \mathrm{~mm})$ and apical $(7 \mathrm{~mm})$ segments as predictors of survival. In multivariate analysis midventricular maximal wall thickness was the only independent predictor of survival. In TTR patients univariate analysis revealed median of maximal wall thickness of the midventricular $(13.5 \mathrm{~mm})$ and apical $(8 \mathrm{~mm})$, but not basal $(16.0 \mathrm{~mm})$ segments as predictors of survival. There was no independent predictor of survival in multivariate analysis of these patients.

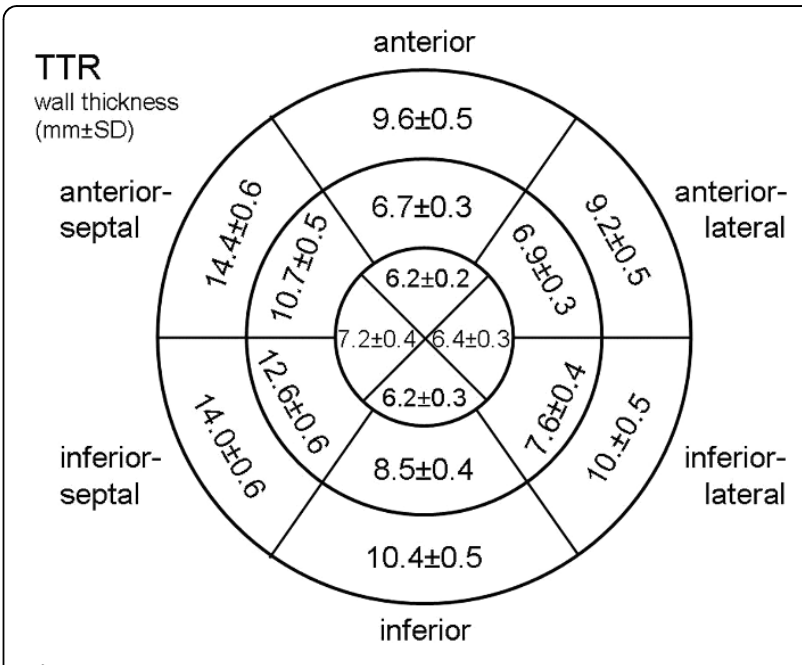

Figure 1

Cardiology, University of Heidelberg, Heidelberg, Germany

( 2013 aus dem Siepen et al; licensee BioMed Central Ltd. This is an Open Access article distributed under the terms of the Creative 


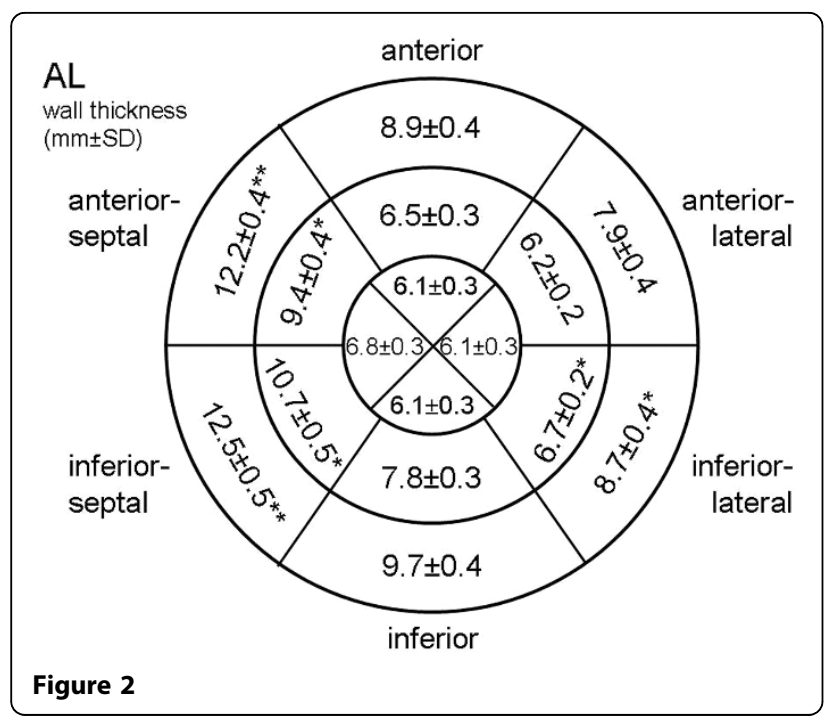

\section{Conclusions}

According to this analysis of a large cohort of patients with different forms of cardiac amyloidosis maximal thickness of LV wall in the midventricular segments appears to be predictive of survival in patients with amyloidosis. Further studies are needed to confirm these results in a larger independent patient cohort especially of the TTR type.

\section{Funding}

none.

Published: 30 January 2013

doi:10.1186/1532-429X-15-S1-P93

Cite this article as: aus dem Siepen et al:: Thickness of the

midventricular left ventricular wall is predictive of survival in different

forms of cardiac amyloidosis. Journal of Cardiovascular Magnetic

Resonance 2013 15(Suppl 1):P93.
Submit your next manuscript to BioMed Central and take full advantage of:

- Convenient online submission

- Thorough peer review

- No space constraints or color figure charges

- Immediate publication on acceptance

- Inclusion in PubMed, CAS, Scopus and Google Scholar

- Research which is freely available for redistribution

Submit your manuscript at www.biomedcentral.com/submit 